\title{
EXPERIMENTAL DYNAMICAL ANALYSIS OF THE MATERIAL PROPERTIES OF TEST PIECES MADE BY ADDITIVE PRODUCTION TECHNOLOGIES
}

\author{
Bálint Ádám KOVÁCS ${ }^{1}$, Péter FICZERE², Ádám TÖRÖK \\ Budapest University of Technology And Economics, Faculty of Transportation Engineering and Vehicle Enginee- \\ ring, Department of Vehicle Elements and Vehicle-Structure Analysis, Budapest, Hungary \\ ${ }^{1}$ enzo-b@hotmail.com \\ ${ }^{2}$ ficzere@kge.bme.hu
}

\begin{abstract}
The recent years, 3D printing has become a hot topic, however, it's hard to design parts without a deep understanding of the material properties. The aim of this study is to estimate the modal parameters and the damping properties via experimental dynamic analysis of a part made from PLA. We will study the effects of the different directions of printing. With the results we can provide data for FEM software input.
\end{abstract}

Keywords: experimental modal analysis, additive manufacturing, natural frequency, mode shapes, polymers.

\section{Introduction}

Additive manufacturing technologies, being relatively new to the scene, are evolving rapidly. And with this comes a fall in the cost of the 3D printed products, making the technology more accessible to a larger audience.

At the same time, the importance of biodegradable plastic has started rising, especially because environmental protection has become an important factor [1]. PLA (polylactic acid) is a popular solution and is widely used mainly because of its low price.

The combination of this flexible technology and environment-friendly material foreshadows the rise of additive manufacturing using PLA. For engineering usage, we need a deeper understanding of the material properties. We researched the available literature regarding PLA's material properties. There are only a few papers that model these properties as well. For the same properties, the studies show various results [2][3][4][5]. The aim of this study is to learn more about the damping properties and the effects of different technological parameters on material properties.

\section{Literature review}

Researching the available literature, we conclude that the orientation of the part in the 3D printer has a significant influence on the material properties: the "standing” test pieces' maximum tensile stress was considerably lower than in the other two cases [3][4]. The proportion varied presumably because of the different in printing parameters. But it's clear that the parts printed in standing position only had 0,4-0,5 times the strength [2] [3].

Perpendicular to the layers' plane the material behaves in a similar way [3]. Considering the results, it can be stated that the parts produced by this method have orthotropic material properties.

\section{Methodology}

Reviews of the literature, experimental, production and practical experiences show that parts made by additive manufacturing do not show isotropic material properties. The orthotropic nature can be explained by the dependence on the orientation of the printing [2][3]. Experimental 
analyses of parts made of polymers raise problems regarding the dynamic modelling.

This paper demonstrates the results of a dynamical analysis on a prism. Three different parts are made, each printed in a different direction (Figure 1.).

Testing it as a cantilever we located the test piece's natural frequencies (bending and torsion), damping ratios and mode shapes in the $\mathrm{f}=0-850$ $\mathrm{Hz}$ range. For every mode, we checked if the mode shape was the classical normal mode or not. As is known, classical normal modes' mode shapes show a standing wave nature, and equivalent to the undamped system's mode shapes. Thus, the mathematical model is significantly simpler. We separated the detected mode shapes into 2 groups: bending and torsion modes. To identify the damping mechanism, we will define regression functions which express the damping factor's frequency dependence [6]. These functions have a direct connection to the damping factor's function known from rheology. The damping factor is the ratio of the loss modulus and the storage modulus [6]. Generally, the loss modulus and the storage modulus are functions of the frequency, therefore the ratio is a function of the frequency.

Via iteration, we will identify the material properties which make the FEM model valid, and the difference between the FEM and EMA model's characteristics (natural frequency, damping factor, mode shapes) are the least.

In the next phase of the study, the comparison will be made qualitatively. For the further project, the FEM model's reduction will be done. We will learn what possibilities we have, to change the damping properties in the chosen FEM environment.

direction of 3D printing

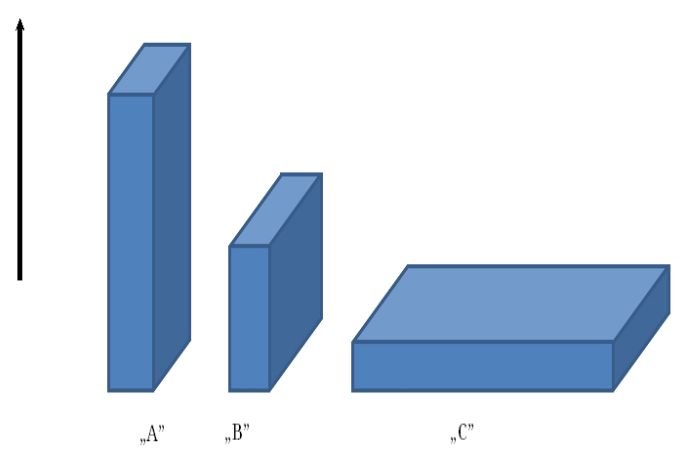

Figure 1. Directions of printing

\subsection{Parameter estimation}

For the measured Frequency Response Function's (FRF) analytic approximation we used the partial fraction form:

$H(j \omega)=\sum_{i=1}^{n}\left[\frac{P_{i}}{j \omega-\lambda_{i}}+\frac{\bar{P}_{i}}{j \omega-\bar{\lambda}_{i}}\right]$

where:
$P_{i}$-residuum of mode i $\left[\frac{\mathrm{m} / \mathrm{sec}}{N}\right]$

$\lambda_{i}$ - the complex eigenvalue of mode i $[\mathrm{rad} / \mathrm{sec}]$

$$
\lambda_{i}=-\sigma_{i}+j \omega_{d, i}
$$

$\sigma_{i}-$ modal damping of mode i

$\omega_{d, i}-$ the damped natural frequency of mode $\mathrm{i}$

$j$ - imaginary part

These modal parameters were estimated by the measure FRF. The individual modes affect the others (Figure 2.), the estimation is inaccurate. We need an optimizing function.

The method minimizes the

$\varepsilon\left(P_{i}, \lambda_{i}\right)=\sum_{r=1}^{N_{r}}\left(H\left(j \omega_{r}\right)-\hat{H}_{r}\right)^{2}$

least squares function $\hat{H}_{r}$ is measured and averaged FRF at $\omega$ the angular frequency.

\section{Partial results}

Figure 3. shows the FRF of the part printed with the method "C".

With this method, we were able to detect 3 natural frequencies. For the classification, we used the Nyquist-plot of the FRF (Table 1.).

In Figure 4. three dominant modal circles can be seen. Further analysis has to be made to estimate the modes with smaller amplitude (near the origin).

\section{Further research}

We define the regression functions mentioned above which express the damping factor's frequency dependence. In the studied interval, we could find only 3 natural frequencies which separated into two groups resulting in two bending and one torsion mode shape. We cannot fit regression functions to this few points (we must always 


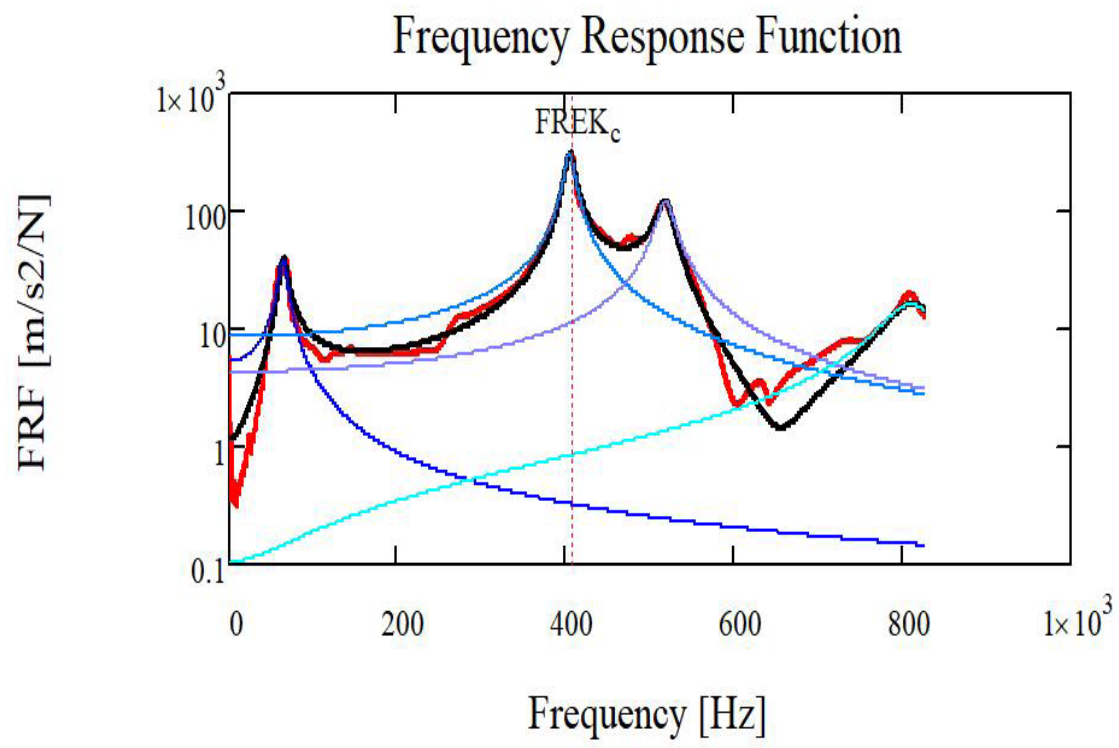

Figure 2. The interference between individual modes

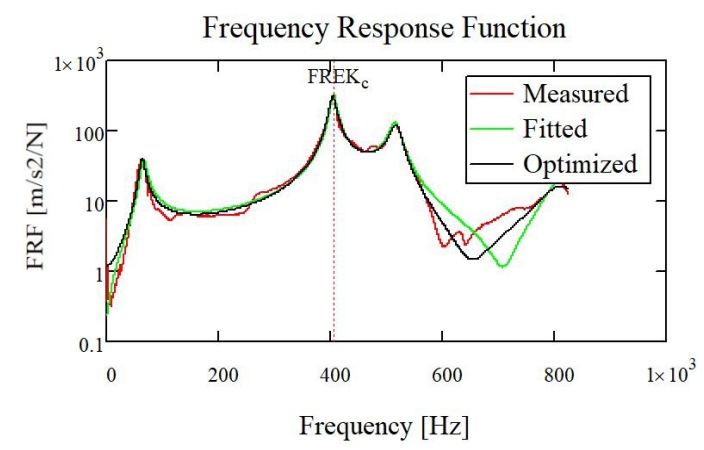

Figure 3. The measured, the fitted and the opti-mized FRFs of part „C”

Table 1. Classification of the mode shapes

\begin{tabular}{|c|c|c|c|}
\hline Mode i & 1 & 2 & 3 \\
\hline$f_{i}$ [Hz] & 65,3 & 406,7 & 520,3 \\
\hline$\xi_{\mathbf{i}}[\%]$ & 5,01 & 1,294 & 1,098 \\
\hline Type & $\mathrm{B}$ & $\mathrm{B}$ & $\mathrm{T}$ \\
\hline
\end{tabular}

avoid interpolation). For the following research, with an expanded measuring range, we should be able to detect enough mode shapes to define the regression functions. We will proceed to do the same for all 3 test specimen.

We expect to have problems with modelling the material properties for the FEM simulations.

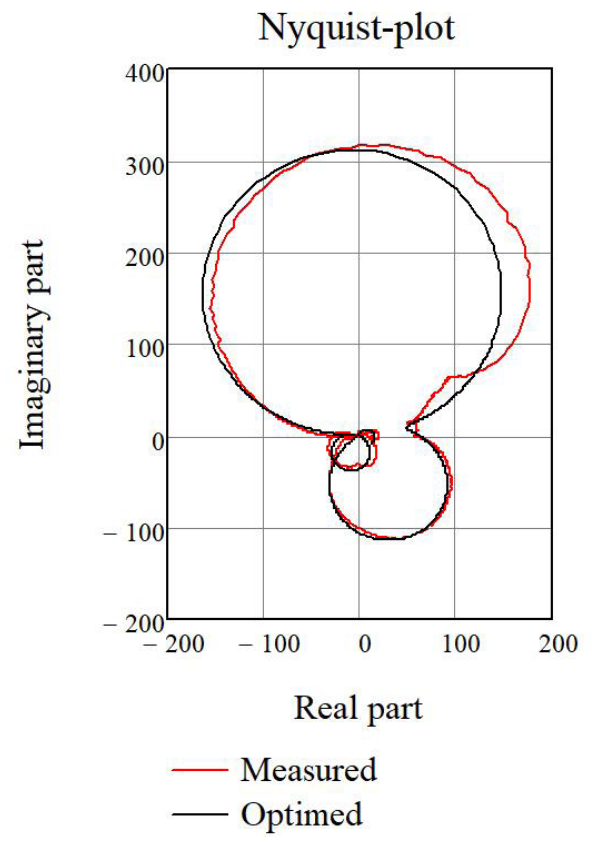

Figure 4. Nyquist-plot of location $7 Z 1 Z$ on part "C"

\section{References}

[1] Bodnár I.: Potenciálisan biodegradábilis, politejsav bázisú polimerek szintézise és vizsgálata, PhD Thesis 2002. 1-26.

[2] Ficzere P.: Orthotrop anyagmodell alkalmazása additív gyártástechnológiával előállított alkatrész méretezése során. GÉP 67/5-6. (2016) 78-81. 
[3] Tisza M., Kovács P. Z., Tóth D.: 3D nyomtatás a jármüiparban. XXIX. microCAD International Multidisciplinary Scientific Conference, University of Miskolc, 9-10 April, 2015.

[4] Kis K.: Additív gyártástechnológiával előállitható rugalmas müanyagok vizsgálata. TDK dolgozat, 2017.10.26., 10-50.
[5] Pauleczki P.: FDM nyomtatási eljárás vizsgálata PLA alapanyag esetében. BSc Thesis, Budapest 2016, 4-34.

[6] Pápai F.: Klasszikus normál módusú lengő-rendszerek csillapítási modellezésének vizsgálata. XI. Magyar Mechanikai Konferencia, MaMeK 2011, Miskolc, Hungary, august 29-31, 2011. 1-11. 